\title{
Gender Implementation in Minangkabau Family
}

\author{
Lili Dasa Putri ${ }^{1}$,* \\ ${ }^{1}$ Department of Non-Formal Education, Faculty of Education, Universitas Negeri Padang, Padang, Indonesia \\ *Email: lilidasaputri@fip.unp.ac.id
}

\begin{abstract}
This study aims to describe gender in Minangkabau customs. Husbands and wives in Minangkabau family have different roles. A wife has a domestic and public role, while the husband has a role as the head of the household and mamak. In Minangkabau families, the instillation of values and characters is given through the basic values of Minangkabau customs includes views on life, views on work, views on time, views on nature and views on others. The value invested through these basic values aims to shape the character of the child to be better and not deviated with the prevailing customary norms.
\end{abstract}

Keywords: gender, husband and wife's role, Minangkabau family

\section{INTRODUCTION}

Gender is one of the hot and interesting issues to discuss. The term gender means a set of attitudes, roles, responsibilities, functions, rights and behaviors that are inherent in men and women due to the formation of the culture or environment of the place where humans grow. In every society, there is always a division of labor between men and women, so that it is known as a gender role that is different between men and women. Gender differences are actually normal or fair things as long as they do not cause gender injustice. Gender injustice can lead to the division of roles and excessive responsibilities on one party, namely women or men. Hence, what is meant by gender is the difference between men and women in roles, functions, rights, responsibilities, and behaviors that are formed by the social, cultural and customary values of the community groups that can change according to time and local conditions [1]

Women occupy special positions in Minangkabau custom due to their descendants and family unity based on the mother's lineage. According to Penghulu[2] mothers (bundo kandung) in Minangkabau have a special position especially about the system of descendants, fields, and houses of residence. However, this situation does not mean that men do not get a place in Minangkabau customs. If seen at glance, a man in Minangkabau has no houses and economic rights, in fact he had two houses and two economic sources, the house of his sister (dunsanak) and his wife's house, as well as the rice fields.

Minang custom treats both men and women equally based on the position they must accept. The line of inheritance is inherited from generation to generation to male nephews, while the lineage is inherited from generation to generation to female nephews. Pepatah Petitih, Customary Law and manners are inherited to all children, nephews and nieces in a nagari even throughout the Minang realm. Thus, there is a balance between men and women in sako. As aforementioned, the title is given to the nephew of the male from the maternal line, and the woman obtains the advantage of being a continuation of the lineage, and as bundo kanduang, the place of questioning and reporting.

\section{METHOD}

The approach used in this study is a qualitative approach using descriptive methods. The use of a qualitative approach is based on the notion that the approach is compatible with the focus of research which essentially wants to explore the object of research or obtain an indepth picture of the role of husbands and wives in the Minangkabau family and community and the planting of values and characters in Minangkabau families. The method employed by the writer in this research was descriptive method. Descriptive method was done by describing events that exist in the present or that are currently happening.

Thus, referring to the characteristics of descriptive method, this study is intended to describe the role of husbands and wives in the Minangkabau family and community and the planting of values and character to children in the Minangkabau family

\section{RESULTS AND DISCUSSION}

\subsection{The Roles of Wives in Minangkabau Family and Community}

The figure of a bundo kanduang (female) in Minangkabau Customs is to show the nature of a woman who devotes 
her full attention to the family, besides trying to realize her children's dream through education which is based on the provisions of Minangkabau customs and Islam [3].

Minangkabau women have two roles, namely domestic roles and public roles. The domestic role carried out by Bundo Kanduang varies greatly. The variations are seen in the context of the type, frequency, and time used. When referring to Penghulu[4], the domestic role is more applied to Bundo Kanduang's role as a wife and a mother of her children. The domestic role is the role played in her own household (as the mother of her children, as the wife of her husband, and as a brother of her brother). In terms of public role, she has a role as sister-in-law, mother, a trader and other jobs that help the household economy. The Minangkabau woman is described as an embroiderer in her household.

\subsection{The Roles of Husband in Minangkabau Family and Community}

Men in the family and Minangkabau community have many roles or functions. Various explanations about men in Minangkabau state that the man has a role that is no less important than the role of women in the Minangkabau family and customs. He is the father in the household, a mamak or niece in his people, in expressions, as a supervisor and caretaker of property and women.

The ninik mamak figure emphasizes leadership or role models that are in line between attitudes and behavior based on Minangkabau adat messages and Islamic teachings [3]. Anak dipangku kamanakan dibimbing (the child is in his lap, the niece is guided). This Minang proverb means that the responsibility of men in Minangkabau is described as the head of the family in his family, and as mamak for his nephew in the house of his sister's daughter. Father raised his child with his income, while Mamak guided his niece with inheritance.

In Minangkabau, men and women have the same economic rights. Judging from the Minangkabau customary norms in the aspect of inheritance (sako and pusako), it is known that in passing down sako and pusako, it is not only for men, but also for women. Amir[5] suggests: immaterial wealth is also called great pusako, such as; 1) title of prince, 2) maternal lineage which is also referred to as sako indu or behavior, or peribawa received from the bloodstream along the maternal line. The term sako indu is equated with the term matrilineal, 3) petatah petitih and customary law, 4) manners or customary manners.

\subsection{Planting the Value and Character of Children in the Minangkabau Family}

In accordance with the stage of development of the community, Minangkabau people when pioneering the compilation of their customs, they took the reality that existed in nature as a source of analogies to the values and norms that govern their lives. They revealed this in the formulation that they considered the truth: Alam takambang jadi guru. Natural law is a source of inspiration that is used as a guide for formulating basic values for norms that will guide them in thinking and doing.

Other classifications of values may be overwhelming. Sprangers argued that the dominant classification of values adopted by a society based on theoretical values, economic values, and religious values Kluckhohn[6] and Alisjahbana[7].

To find out the basic values adopted by the Minangkabau people, we can see from what they say about themselves, about their society, and their environment, or by observing their behavior. By learning the word (kato), they will be able to express basic values and norms that hold their lives, say their philosophy of life regarding the meaning of life, the meaning of time, the meaning of nature, the meaning of work for life, and individual meaning in social relations. Words (kato) as contained and revealed in the basic principles or formulations of truth, petatah-petitih, advice, mamangan and other symbolic expressions about themselves in relation to nature, with their socio-cultural environment. All of which are the media which can be used in knowing and understanding the dominant values that they adhere to.

\section{CONCLUSION}

Minang custom has the values of gender equality and justice by providing the values of rights and obligations and responsibilities between men and women proportionally in accordance with their status and function both in the family, indigenous people and in traditional governance. In the economic and inheritance aspects, women have a special position about the hereditary system, fields, and houses of residence. A man has economic rights, with two sources of his sister house and his wife house. Meaanwhile, from the aspect of the Sako inheritance, the formless wealth in Minang custom is inherited from generation to generation according to certain paths. Women as bundo kanduang become the main and decisive source in making decisions. The implications of the values of gender equality and fairness in the family of women have a position as bundo kanduang, which has a dominant and public role. The role of men in Minangkabau in the household is as father and in his extended family as mamak. The planting of values and character of children in the Minangkabau family applies the basic values used in Minangkabau customs, namely views on life, views on work, views on time, views on nature, and views on others. Planting the basic values that are applied in the Minangkabau family aims to shape the character of the children which is in line with the customary rules and norms that apply to the Minangkabau itself. 


\section{REFERENCES}

[1] H. Puspitawati, Gender dan Keluarga, no. 11. Bogor: IPB Press, 2012.

[2] H. I. H. D. R. Penghulu, Rangkaian Mustika Adat Basandi Syarak di Minang Kabau. Bandung: Pt.Remaja Rosdakarya, 1997.

[3] J. Jamna, Pendidikan Matrilineal. Padang: Guna Tama, 2004.

[4] I. H. D. R. Penghulu, Pegangan Penghulu, Bundo Kanduang dan Pidato Alua Pasambahan Adat di Minangkabau. Bandung: Remadja Rosdakarya, 1974.

[5] A. M.S., Adat Minangkabau: Pola dan Tujuan Hidup Orang Minang. Jakarta: PT. Mutiara Sumber Widya, 2007.

[6] C. Kluckhohn, The Study of Culturen., Stanford U. New York, 1951.

[7] S. takdir Alisjabana, The Concept of Language Standardisation and Its Applicaton to the Indonesian language. Kuala Lumpur: University of Malaya Press, 1974. 